\title{
A Research on the 4th Generation Intelligent Energy-Saving Solar Water Heating Tank
}

\author{
Chun-Te Lee ${ }^{1}\left(\mathbb{D}\right.$, Ping-Tsan Ho ${ }^{1, *} \mathbb{C}$, Yen-Yi Lee ${ }^{2}$ and Liang-Bi Chen ${ }^{3, * \mathbb{C}}$ \\ 1 Department of Leisure and Sport Management, Cheng-Shiu University, Kaohsiung City 833, Taiwan; \\ charter@gcloud.csu.edu.tw \\ 2 Department of Food and Beverage Management, Cheng-Shiu University, Kaohsiung City 833, Taiwan; \\ leeyenyi@gcloud.csu.edu.tw \\ 3 Department of Computer Science and Information Engineering, \\ National Penghu University of Science and Technology, Magong City, Penghu County 880, Taiwan \\ * Correspondence: k0630@gcloud.csu.edu.tw (P.-T.H.); liangbi.chen@gmail.com (L.-B.C.); \\ Tel.: +886-918-563-407 (P.-T.H.); +886-929-160-502 (L.-B.C.)
}

Received: 5 October 2020; Accepted: 15 November 2020; Published: 18 November 2020

\begin{abstract}
Currently, the 1st generation and 2nd generation solar water heating tanks' design is unsatisfactory in the current use situation. When hot water is used with the hot water being consumed, thus cold water will be added into the same tank at the same time, resulting in a significant drop in the temperature of the hot water in the tank and making it necessary to use an additional electric heating rod for reheating. To address this shortcoming, a 3rd generation solar water heating tank was designed to improve the situation. In other words, a "movable dividing disk" is added inside the tank to completely isolate the hot water from the cold water so that the entire tank of hot water can be $100 \%$ utilized. However, when the hot water is exhausted, the 3rd generation solar water heating tank must adopt an electric heating rod to reheat the entire tank of water or make an additional small heating tank. To solve this problem, this article develops the 4th generation intelligent energy-saving solar water heating tank, in which a "fixed dividing disk" is installed inside the water heating tank to create a cold-water heating zone of about $10 \%$ of the total capacity for local heating. This allows for an efficient and faster hot water supply, saving about $90 \%$ of energy when the first tank of hot water is used up and a separate electric heating rod is used for heating.
\end{abstract}

Keywords: solar water heating tank; dividing disk; electric heating rod

\section{Introduction}

The world's residential electricity consumption is growing rapidly, mainly for domestic water heating [1]. It is estimated that domestic water heating accounts for about $15-20 \%$ of the total domestic electricity consumption of an average household in Hong Kong and the United States [2]. With such a high demand for energy, there has been a growing interest in more efficient installations, especially since the doubling of oil prices in 2005 led to the increase in electricity rates [3].

Global warming keeps worsening and climate anomalies are occurring increasingly frequently around the world. After the Kyoto Protocol, which aims to curb the global greenhouse gas emissions, came into force on 16 February 2005, the innovation of energy technologies and the change of social behavior for energy conservation will be an effective strategy for carbon dioxide reduction [4]. Due to the growing influence of global warming and the rapid changes in the ecological environment, many unusual ecological crises have started to occur all over the world. Therefore, the search for "Renewable Energy" is a matter of great importance to all governmental and non-governmental organizations [5,6]. For the U.S., the U.K., and China, the goal is for renewable energy to account 
for at least $20 \%$ of total electricity generation by 2020 , and it is expected that renewable energy will contribute more than $50 \%$ of total electricity generation in some countries by 2050 [7].

Economic development depends on an adequate supply of energy, and there is an urgent need for a clean, environmental-friendly and inexhaustible source of renewable energy, and the best choice is "solar energy". The sun emits $3.845 \times 10^{26} \mathrm{~J}$ of energy per second and the earth receives $1.743 \times 10^{17} \mathrm{~J}$ of energy therefrom per second, which is equivalent to about the heat quantity generated by 6.1 million tons of coal burning and 16,700 times the global demand [8]. In terms of the conversion and application of solar radiation, it can be divided into solar water heating systems, solar heater systems, solar air conditioning and refrigeration systems, solar power generation and so on [9] according to the solar energy density. For low temperature applications $\left(<100^{\circ} \mathrm{C}\right)$, it is mainly used for water-heating and warming. For medium temperature applications $\left(100\right.$ to $\left.200^{\circ} \mathrm{C}\right)$, it is for industrial heating and air conditioning. For high-temperature applications $\left(>200{ }^{\circ} \mathrm{C}\right)$, it focuses on solar power generation, smelting and toxic decomposition [10].

The solar water heating system uses solar collectors (such as flat plate or vacuum tube type) to convert solar radiation into thermal energy to heat up water. Such products were introduced as early as 1891, and by 2001 solar collectors had been installed over 70 million square meters worldwide [11].

It is known that water heaters include gas water heater, electric water heater, heat pump water heater and solar water heater. Of these four types of water heaters, the heat pump water heater and solar water heater are the most energy efficient and environmentally friendly. The difference in energy efficiency between these two types of water heaters is not significant and must be determined by the weather and region. Generally, if the annual average sunshine hours are more than $1 / 2$ of the year, reaching over 210 sunshine days (daily sunshine hours of more than $4 \mathrm{~h}$ ), using a solar water heater will save more energy and money. Conversely, if the number of sunshine days is less than 180 days, the heat pump hot water system will be more cost-efficient than the solar water heater [12].

Taiwan is a very sunny country, even in the northern part of Taiwan where the latitude is higher, people can still use solar water heaters. However, one of the most unbelievable solar-related products commercially available on the market is the solar water heater. Why is there a need to install an electric heating rod for secondary heating when claimed to be the cleanest and most environmentally friendly renewable energy? The reason for this is that the design of the water storage tank of the conventional 1st generation water heater was not ideal. The water storage tank was hollow and could not separate the hot water from the cold water added thereafter. When bathing, with the hot water being consumed, the temperature of the hot water still in the tank drops significantly because the cold water is being replenished therein, so it is necessary to use an additional electric heating device to reheat the water, thus increasing the energy consumption.

Many homes around the world use electric water heaters (EWHs) to generate and store hot water, and the energy required can be supplied by solar energy using solar panels. For a single tank or auxiliary tanks (parallel or series connection), an electric heater is the most common heating element used in water heating storage systems [13]. The only drawback of an electric heating system is that it consumes a large amount of electrical energy to produce the required hot water. Although these systems are driven by electrical energy, a disadvantage compared to direct solar water heaters, they are still widely used due to their practicality and low installation cost [14].

Aviv et al. [15] investigated the results of inputting and mixing cold and hot water in a vertical water tank. In such a system, the speed of mixing of the hot water produced and the incoming cold water will affect the thermal performance of the storage tank. The researchers recommended using a horizontal dividing disk above the vertical inlet at the bottom of the tank, and they found that the dividing disk would not be needed for a very low flow rate (2-3 L/min) of incoming cold water. However, for a higher water flow rate $(5-7 \mathrm{~L} / \mathrm{min})$, it was found that a single stir was sufficient to mix the hot and cold water evenly.

Hegazy [3] stated that thermal stratification is affected by the length-to-width ratio of the inlet of the incoming cold water and the storage tank. He proposed a new design for an inlet diffuser 
(wedged type) in which the incoming cold water does not interfere with the hot water. It directs the cold water flow to the bottom of the tank and establishes a cold water pan partition at the bottom of the tank. This new design reduces the mixing speed of hot and cold water.

Assari et al. [16] investigated the impact of the water inlet and outlet location of the fluid on thermal performance in a cylindrical storage tank. It was found that location of hot water inlet to the tank has a high impact on performance enhancement. With the increase in vertical height of the heating location, better performance was obtained due to less mixing of hot and cold water.

Due to the unsatisfactory design of the storage tank of a conventional solar water heater, in which while the hot water is being consumed during bathing, the cold water is replenished at the same time, resulting in a significant drop in the temperature of the hot water in the storage tank, some manufacturers adopted the above practice of using a horizontal dividing disk (2nd generation solar water heating tank) near the water inlet. This new design effectively reduces the mixing speed of hot and cold water, but unfortunately, it can only reduce the "mixing speed of hot and cold water" and eventually the temperature of the hot water in the tank will still drop.

To address this shortcoming, the 3rd generation solar water heating tank is designed to improve the situation. It adds a "movable dividing disk" inside the tank to completely isolate the hot water and cold water, so that the entire storage tank of hot water is $100 \%$ utilized. However, there is an invisible drawback to this new design. For the 3rd generation solar water heating tank, when the hot water is exhausted and the user wants to continue using hot water, an electric heating rod must be used to reheat the entire tank of water, or a separate small heating tank needs to be added. To address this issue, this article proposes the 4th generation intelligent energy-saving solar water heating tank, in which a "fixed dividing disk" is installed inside the water heating tank to separate a small space for local heating so that the hot water can be supplied more efficiently and quickly.

\section{New Structure of the Solar Water Heating Tank}

Figure 1 below is the "natural cycle type of solar water heater". The water in the solar collector absorbs the solar radiation heat. When the temperature rises, the density decreases and then rises to the storage bucket. The colder water in the storage bucket will flow down to the collector, generating a natural convection cycle and storing it. The water in the bucket is heated. The natural circulation type is mostly used in the natural circulation of small domestic hot water. This article is mainly aimed at improving the structure of the "water storage tank".

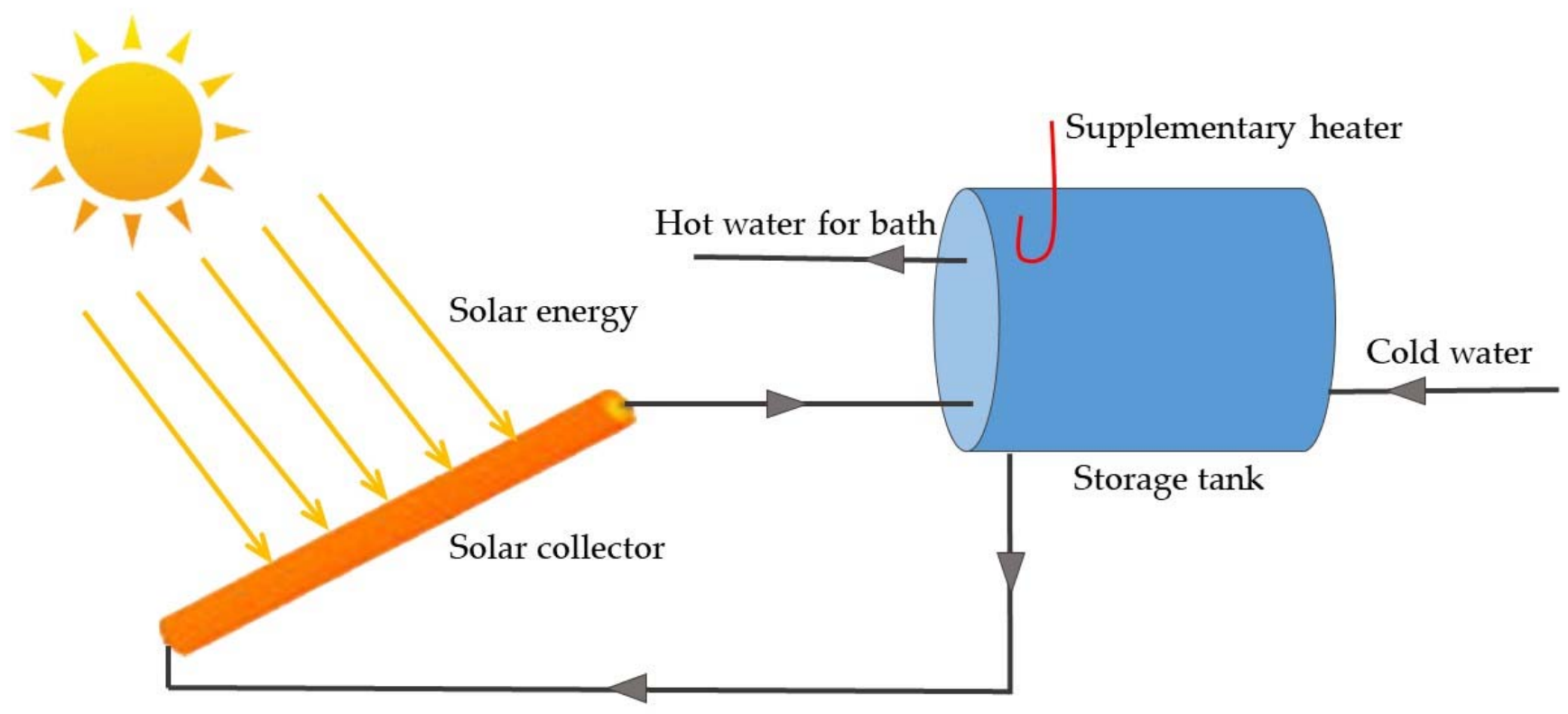

Figure 1. Natural cycle type of the solar water heater [17]. 


\subsection{Overview of Previous Products}

Since the design of the conventional solar water heating tank is not ideal, with the problem of mixing hot and cold water, manufacturers and research teams have proposed various solutions. The following discusses the differences between the conventional and improved type of water heating tanks.

\subsubsection{1st Generation of the Solar Water Heating Tank}

Why do solar water heaters, which can use sunlight for heating, need to be equipped with an electric heating rod for secondary heating? In addition to having to use electricity for water heating on cloudy days, one other reason is that hot water is needed to use with the hot water being consumed, cold water is filled in, and causes the temperature of the hot water in the storage tank to drop. When it happens, it becomes necessary to heat the water by electricity. Figure 2 is a cross-sectional view of a conventional 1st generation solar water heating tank.

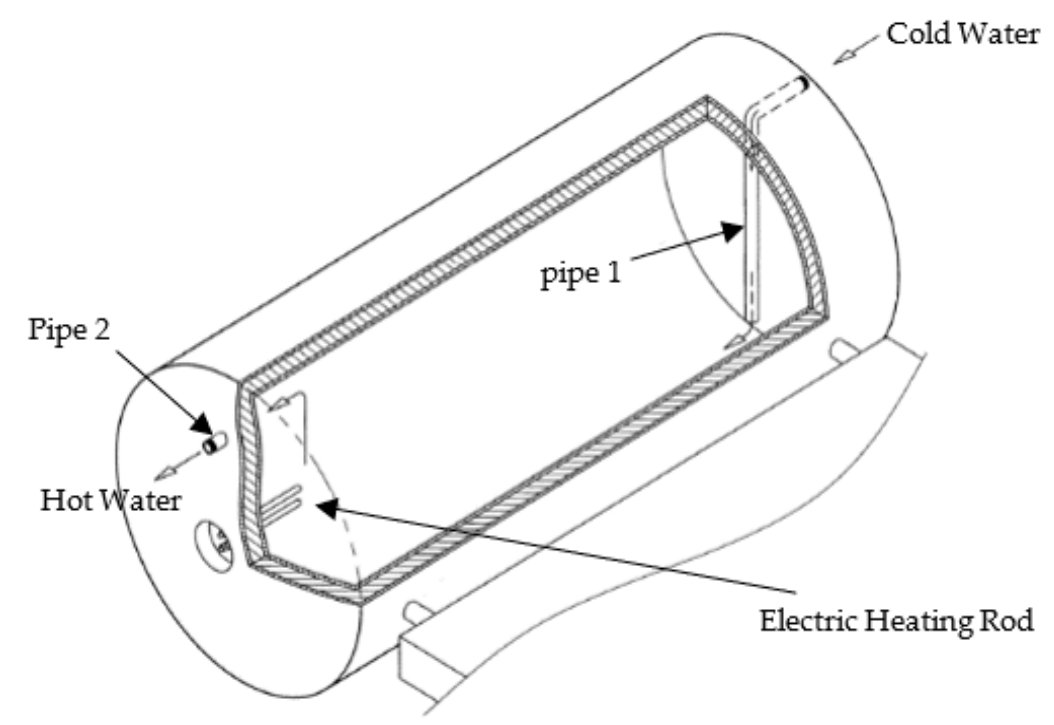

Figure 2. Cross-section view of a conventional 1st generation solar water heating tank [18].

The old type of the water storage tank is equipped with an inlet pipe 1 and an outlet pipe 2 at both ends. When using hot water, hot water will flow out of the outlet pipe 2, while the water source of cold water will be replenished through the inlet pipe 1 into the tank (some types use pressurized motors to inject cold water), and then the cold water will be mixed with the hot water stored in the tank, resulting in a sudden drop in the temperature of the hot water. Therefore, in order to keep the temperature of the hot water in the storage tank within a predetermined range, an electric heating rod is usually added to heat the water in the tank. However, due to the large capacity of the tank (usually $400 \mathrm{~L}$ ), the heater must consume more electrical energy and longer heating time to heat the water in the tank. Therefore, to the user, not only does it fail to save energy effectively, it also leads to the problem of energy wastage.

\subsubsection{2nd Generation of Solar Water Heating Tank}

In response to the governmental policy of energy saving and carbon reduction, some manufacturers have proposed solutions to improve the aforementioned problems of water temperature droppage in water tanks, higher energy consumption and longer heating time when heating up water using electricity. The solution is to add a "fixed dividing disk" inside the tank to separate the tank into two spaces (the left side is the hot water area and the right side is the buffer area), and then uses a pilot tube to connect the two spaces, so that when the cold water is introduced into the tank, it will first be 
buffered in a separate space before being introduced into the location of lower temperature in another space, thereby guiding the direction of water flow and slowing down the mixing speed of hot and cold water, as shown in Figure 3.

From Figure 3, it can be seen that the "fixed dividing disk" separates the tank into two spaces, the hot water area and the buffer area, and the pilot tube connects the two spaces. The inlet of the pilot tube at the upper portion of the buffer area and the outlet at the lower portion of the hot water area. Since the hot water is less dense than the cold water, hot water will be at the top and the cold water will be concentrated at the bottom in both the hot water area and the buffer area, so such a connection method will ensure that the water of higher temperature will be used. In the same way, the hot water outlet of the entire water heating tank is also located at the top, while the cold water inlet is located at the bottom. Unfortunately, this only reduces the "mixing speed of hot and cold water" and eventually the temperature of the hot water in the tank will still drop.

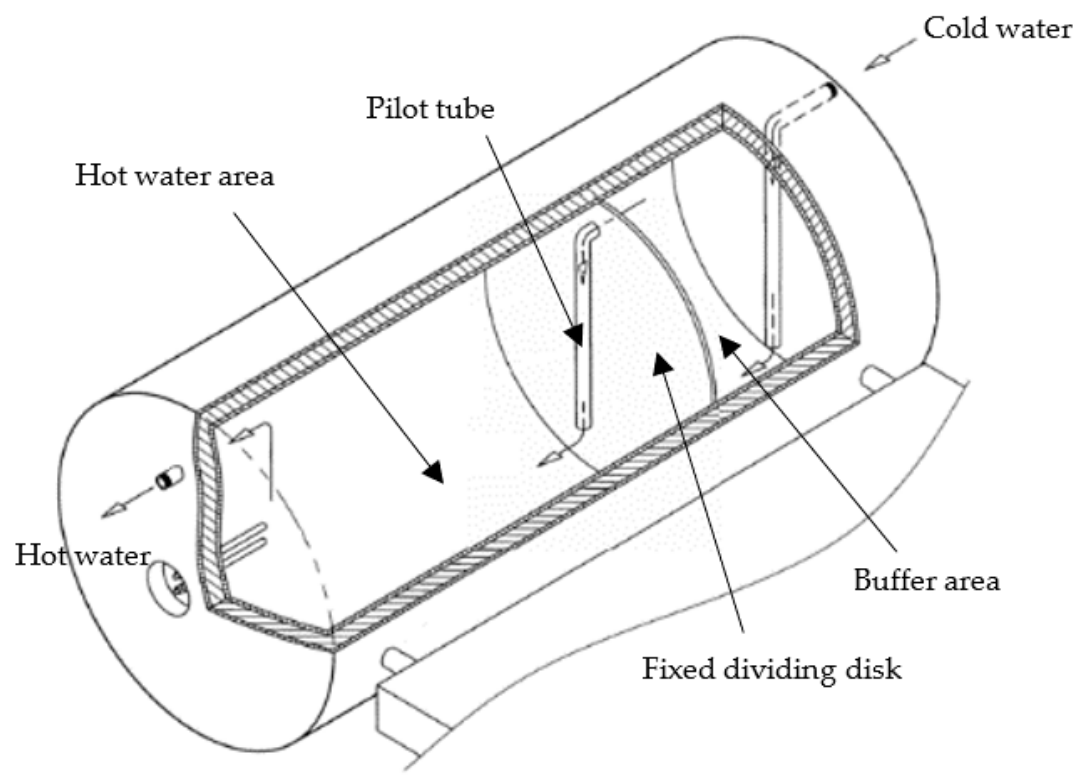

Figure 3. Cross-section view of an improved 2nd generation solar water heating tank [19].

\subsubsection{3rd Generation of the Solar Water Heating Tank}

Although the above design can reduce the problem of reduced water temperature of the storage tank, but the fact is that the cold water will still flow through the pilot tube to the hot water area, so it can only slow down the mixing speed of hot and cold water but cannot achieve a complete isolation effect. In the 3rd generation solar water heating tank, a movable dividing disk is added inside the tank to completely separate hot and cold water, so that hot and cold water can be completely isolated and will not be mixed, as shown in Figure 3 .

The "movable dividing disk" of this new design can move left and right. It locates at the far right end at the beginning. When hot water flows out and cold water fills in, the dividing disk will be slowly pushed to the left by the water pressure, so the hot and cold water will not be mixed together. Once the dividing disk hits the far left end, the water motor pump will be activated to fill the cold water from the right side of the dividing disk to the left side of the disk until the disk returns to the far right end. The reason of pushing the dividing disk back to the far right end is because the dividing disk must remain at that position when the sunlight is utilized to heat up the water in the tank the next day, or it will interfere with the heating action. Figure 4 shows a physical model of the 3rd generation solar water heating tank. Figure 5 shows a physical model of the 3rd generation solar water heating tank. 
The Water Motor Pump

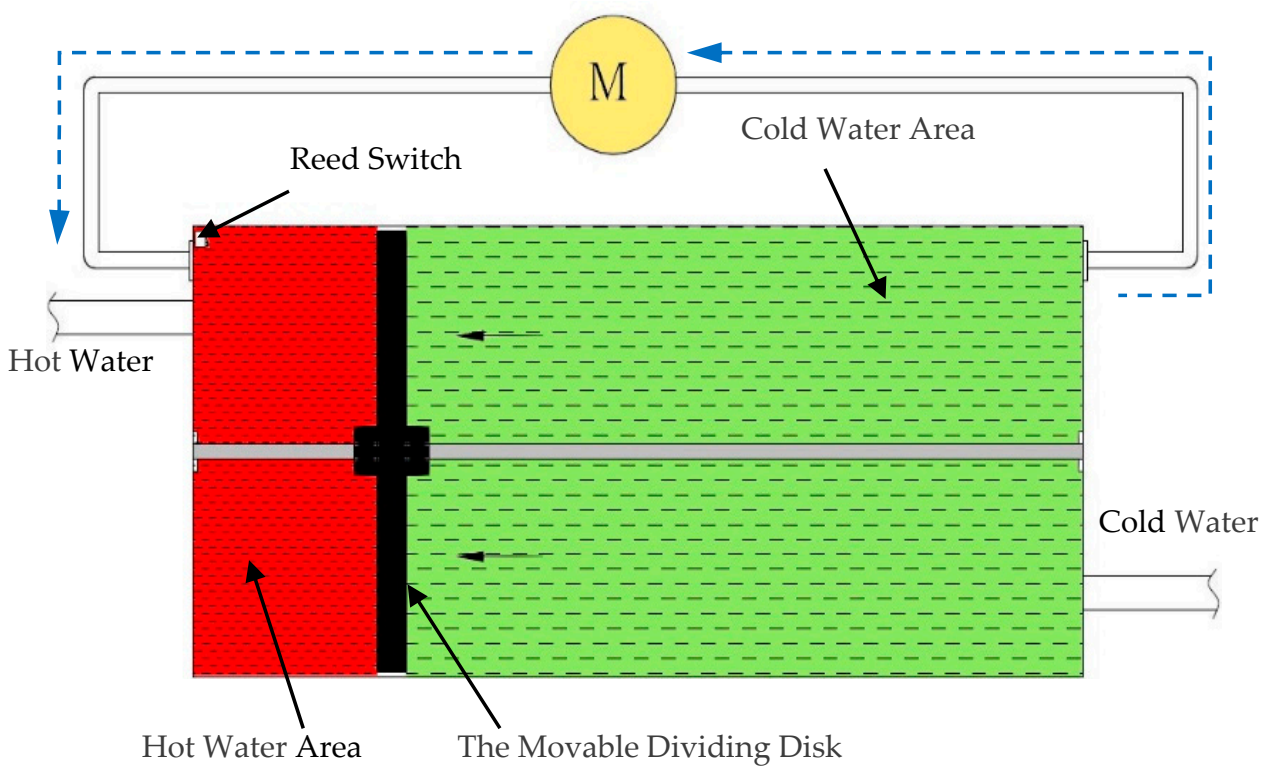

Figure 4. The 3rd generation solar water heating tank [20].

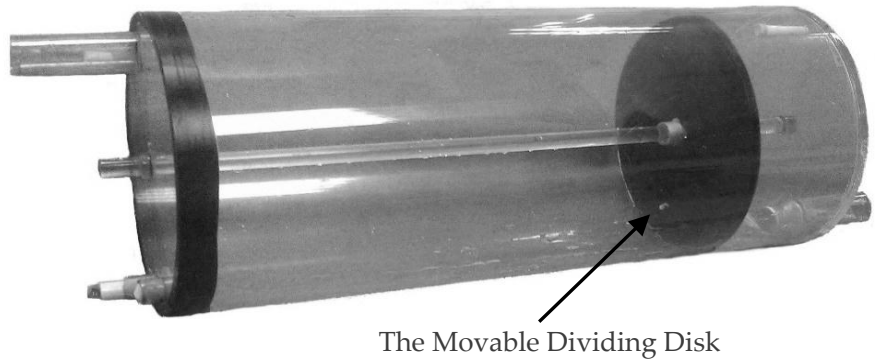

Figure 5. The physical model of the 3rd generation solar water heating tank.

The material of the dividing disk is high impact polystyrene (HIPS). It is an impact-resistant polystyrene product produced by adding polybutylene rubber pellets to polystyrene and is the best choice for the "dividing disks" because of its impact resistance and heat insulation. When making the dividing disk, be sure to make it fit snugly into the storage tank. It is recommended that the gap there between should be less than $1 \mathrm{~mm}$ so that the dividing disk will not leak when pushed to the left by water pressure, which can slow down the movement of the disk [21]. Figure 6 shows the moving process of the dividing disk of the 3rd generation solar water heating tank.

It can be seen from the above figure that when hot water flows out and cold water fills in, the movable dividing disk will be pushed slowly to the left by water pressure, and the hot water and cold water are completely separated during the pushing process. Therefore, the design of the 3rd generation solar water heating tank ensures $100 \%$ utilization of hot water. While this product is already very energy efficient, there remains a problem-when the tank runs out of hot water and the user still needs to continue using hot water, the whole tank has to be heated by the electric heating rod inside the tank, which consumes a lot of energy and money.

\subsection{Design of the Product}

The previous 3rd generation solar water heating tank consumes a lot of energy and money during secondary heating. Therefore, some manufacturers put an additional small water heating tank to the existing water storage tank. This way, the secondary heating is conducted on the small tank instead of the original large storage tank. While this design solves the problem, it has the disadvantages of 
requiring additional piping and wasting the cost of an additional tank, which defies the purpose of environmental protection and energy conservation.

To solve this problem, this article proposes the 4th generation solar water heating tank, in which a "fixed dividing disk" is installed inside the 3rd generation solar water heating tank so that a small space is isolated and can be used as a heating area for local heating. This will result in an efficient and faster supply of hot water, as shown in Figure 7.

In the above figure, the "fixed dividing disk" and "movable dividing disk" divide the water storage tank area into a cold-water area, a hot water area and a heating area. The cold-water area and hot water area together is equivalent to the " 3 rd generation solar water heating tank", and the hot water area is the additional space separated by the "fixed dividing disk". Therefore, it can retain the advantages of the "3rd generation solar water heating tank" and has a heating area for local heating, eliminating the need of additional piping and saving the cost of an additional storage tank. Figure 8 shows the moving process of dividing disks of the 4th generation solar water heating tank.
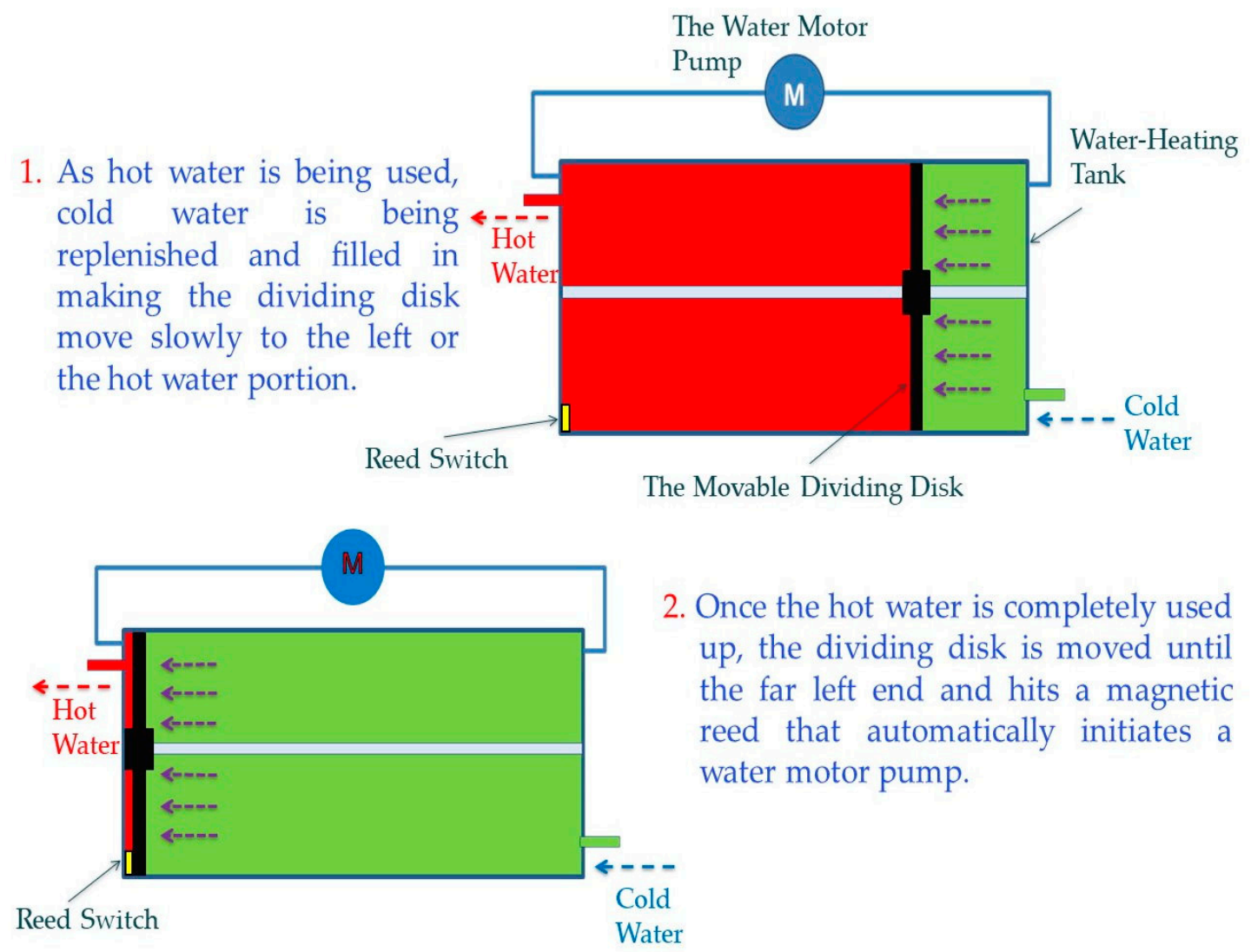

2. Once the hot water is completely used up, the dividing disk is moved until the far left end and hits a magnetic reed that automatically initiates a water motor pump.

3. When the water motor pump is initiated, it will pump water from one end to the other while moving the dividing disk from the left end towards the right end bringing it to its original position.

The Water Motor Pump

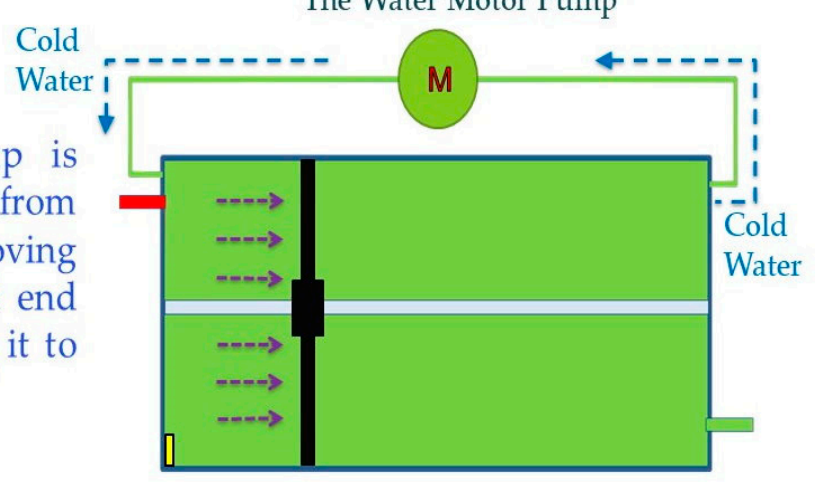

Figure 6. The moving process of the dividing disk of the 3rd generation solar water heating tank. 


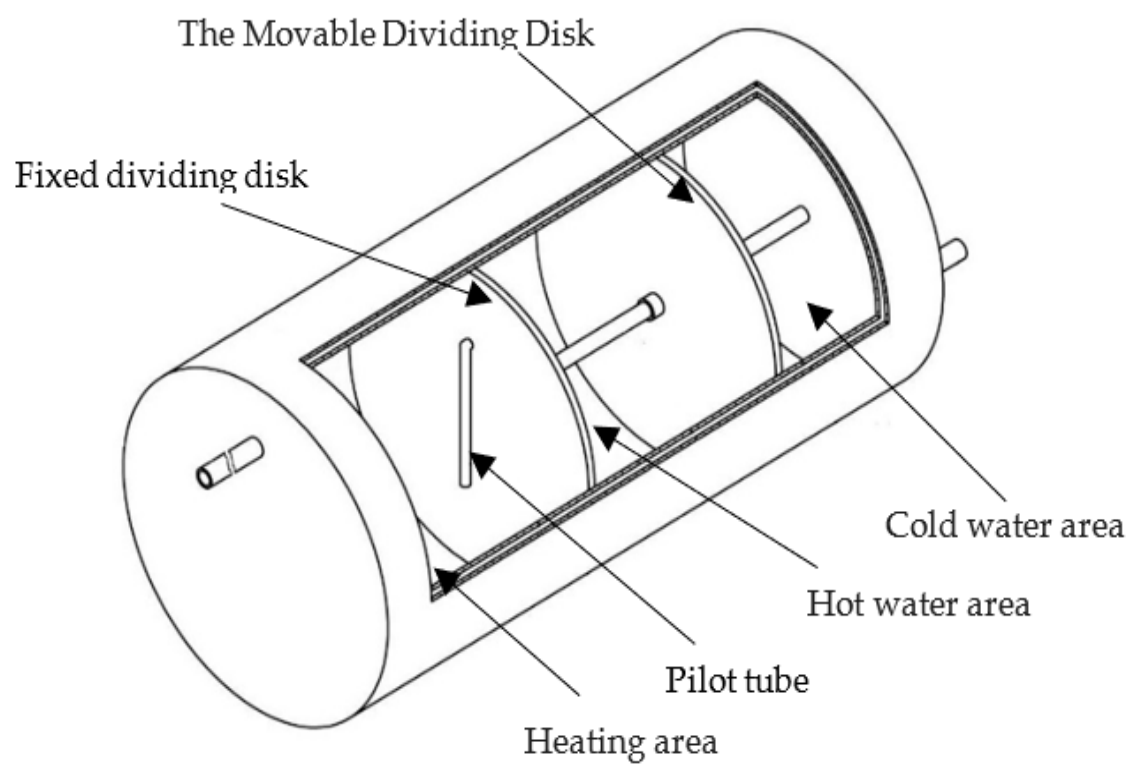

Figure 7. Cross-section view of 4 th generation solar water heating tank.

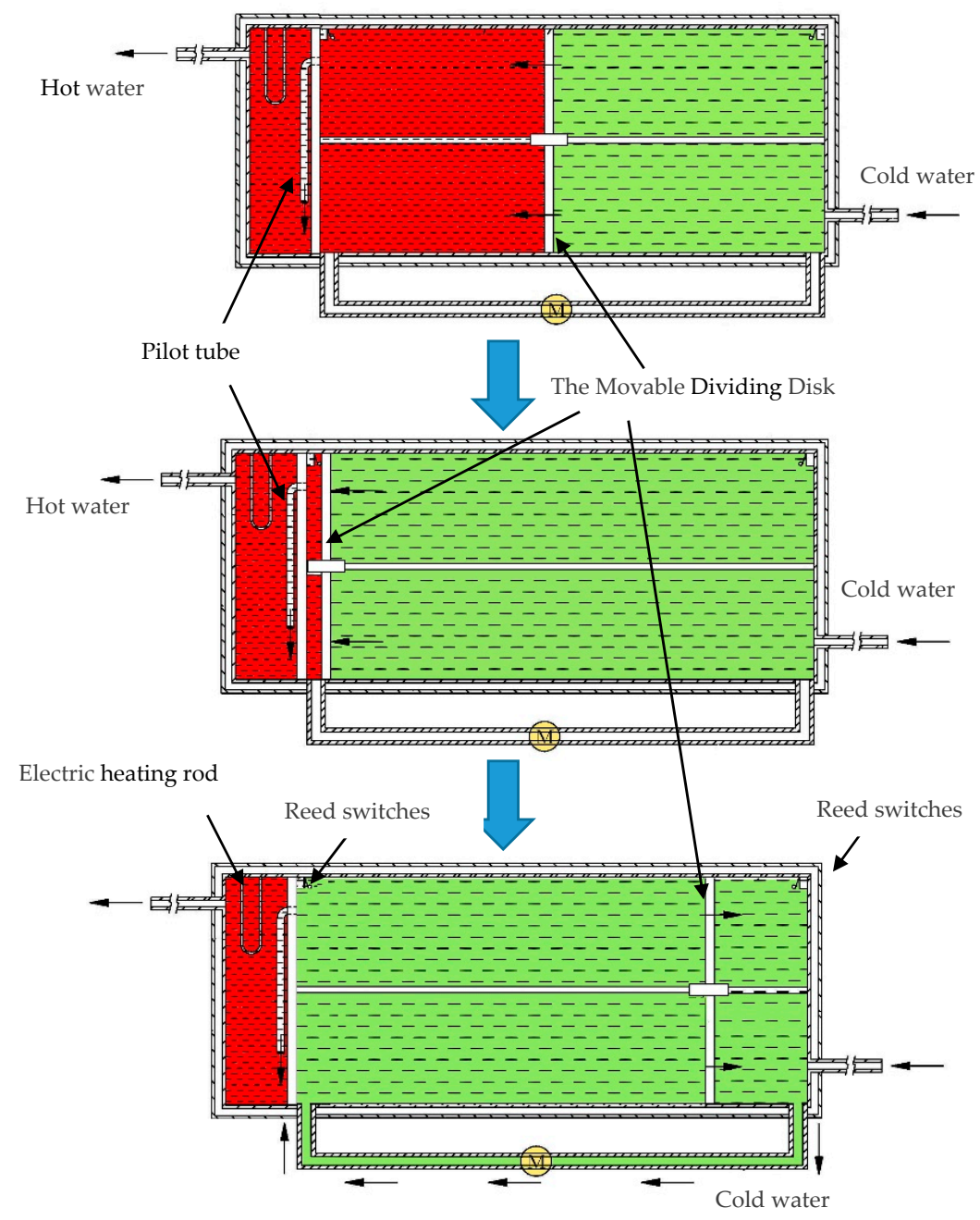

Figure 8. The moving process of dividing disks of the 4th generation solar water heating tank. 
From the above figure, it is known that Figure 8 has the same moving principle as that of Figure 6. Furthermore, Figures 7 and 8 show that the pilot tube of the fixed dividing disk connects the hot water area and the heating area. Again, since the density of hot water is lower than that of cold water, the inlet of the pilot tube is put at the top of the hot water area and the outlet thereof at the bottom of the heating area.

Figure 9 shows the validation prototype of this work. Reed switches must be installed on both sides of the water storage tank to detect the movable dividing disk's position. The pumping motor can be activated to move the movable dividing disk back to its original position, and an automatically controlled circuit is used in this work.

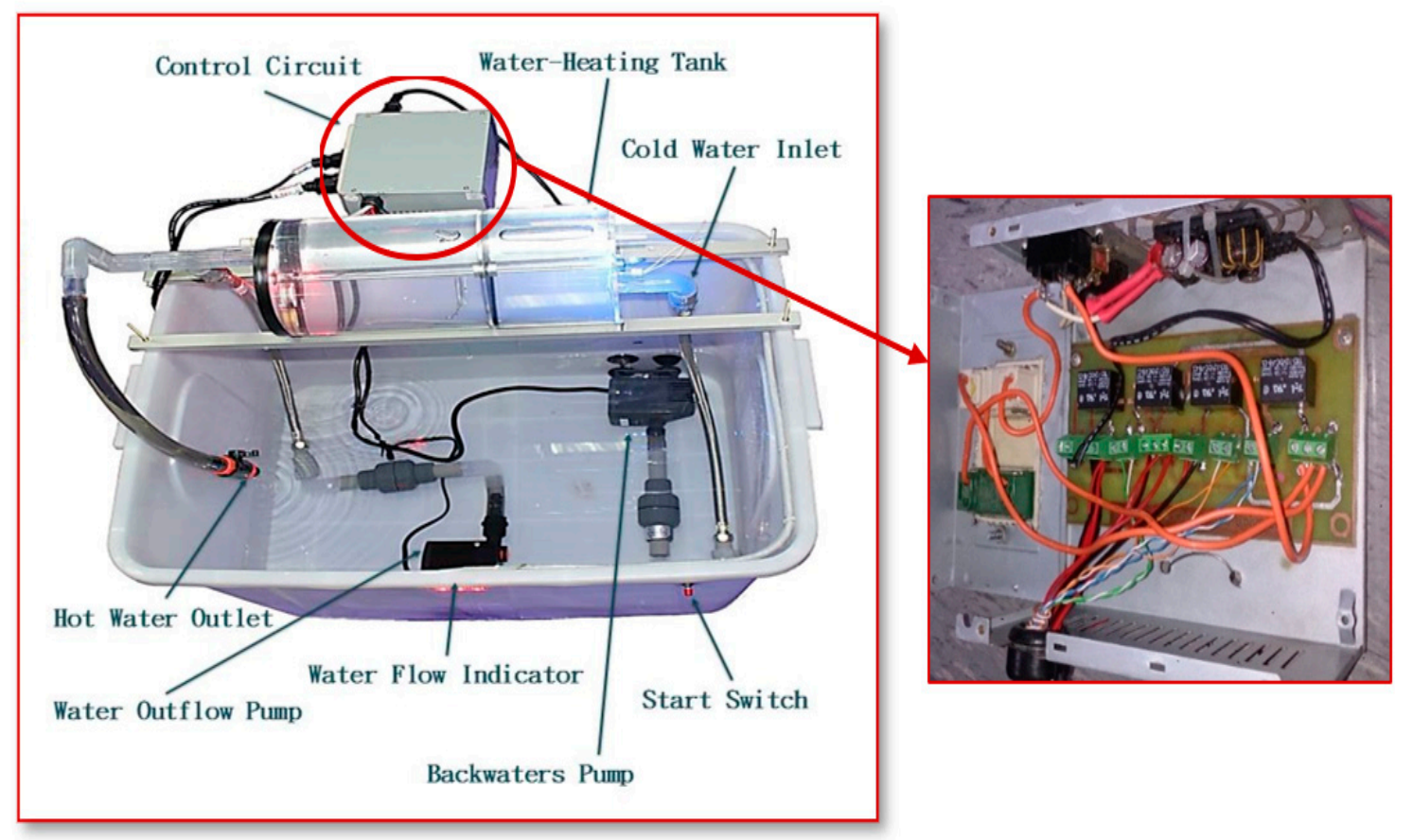

Figure 9. The validation prototype of this work.

\section{Experiment and Discussion}

From Figure 8, it is known that the 4th generation solar water heating tank can be regarded as a combination of the 3rd generation solar water heating tank and 2nd generation solar water heating tank. It retains the "movable dividing disk" of the 3rd generation solar water heating tank while adding the "fixed dividing disk" of the 2nd generation solar water heating tank. Therefore, the impacts are only studied both "movable dividing disk" and "fixed dividing disk" have on the water heating efficiency of the storage tank to know the efficiency of the 4th generation solar water heating tank, and the optimal position of the fixed dividing disk.

An experiment was conduced to verify the effectiveness of the "movable dividing disk" of the 3rd generation solar water heating tank and to test the optimal position of the "fixed dividing disk" of the 2nd generation solar water heating tank. Especially for making a storage tank model to test the changes in water temperature in the 1st generation, 2nd generation and 3rd generation water heating tanks. The test environment and hypothesis for this experiment were as follows.

- Water storage tank has a capacity of $400 \mathrm{~L}$; the temperature of hot water is $60{ }^{\circ} \mathrm{C}$.

- $\quad$ The cold water injected is $20^{\circ} \mathrm{C}$.

- $\quad$ Bathing for each person consumes $50 \mathrm{~L}$ of water.

- There is a 15-minute interval between the shower of each person.

- The water temperature will be measured from the water outlet. 
The actual experiment used a smaller $2000 \mathrm{~mL}$ tank to simulate a $400 \mathrm{~L}$ storage tank, so the water consumption of $50 \mathrm{~L}$ per person for bathing was proportionally reduced to $250 \mathrm{~mL}$. When conducting experiments with the "fixed dividing disks" of the 2 nd generation solar water heating tank, the tank was then divided into 20 equal parts and we placed the fixed dividing disks in the positions of $1 / 20,2 / 20$, $3 / 20, \ldots 10 / 20$, etc. to measure the temperature change after each person takes a bath. The Figure 10 shows the dividing disk at the $4 / 20$ position.

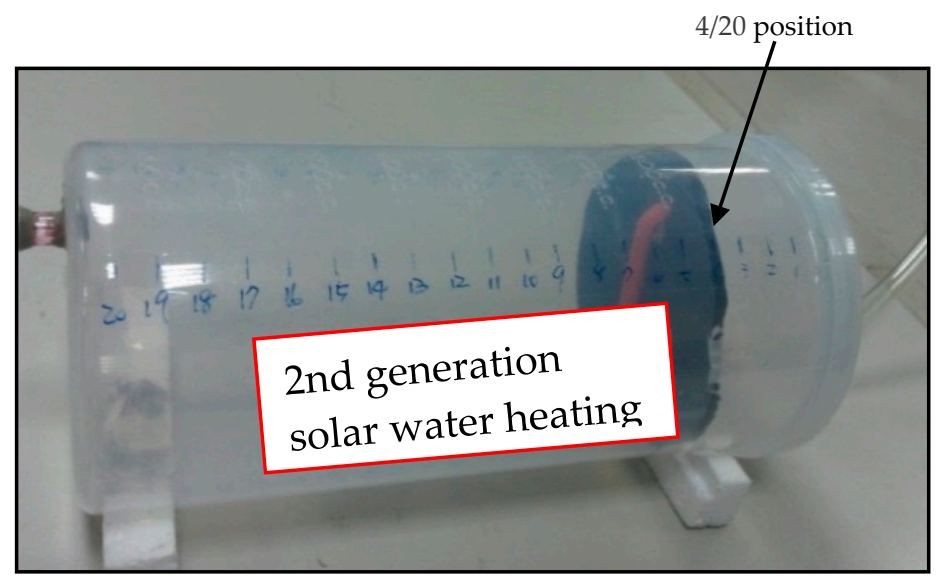

Figure 10. Photo of "fixed dividing disk" of the 2nd generation solar water heating tank model.

In addition to the commonly used $400 \mathrm{~L}$ water storage tank on the market, there were other sizes of 100 L, 200 L, 300 L, 400 L, 600 L, 800 L, etc. If you want to use the same $2000 \mathrm{~mL}$ small bucket for simulation, the bath water consumption during simulation must be adjusted accordingly, as shown in Table 1. Moreover, the list of instruments adopted for this experiment was also provided, as can be seen in Table 2. Table 3 shows the experimental data obtained by using a $2000 \mathrm{~mL}$ tank to simulate a $400 \mathrm{~L}$ tank, which mainly measured the change of water temperature after each person takes a bath using hot water.

Unless it is a particularly enlarged water storage tank, the water storage tank can only bathe about 5-6 people, so this experiment only set up to 6 people to bathe. When the hot water in the water storage tank was exhausted for shower 7,8,9 and 10, the general practice was to use an electric heating rod for heating.

Table 3 is the actual experimental data obtained by using a $2000 \mathrm{~mL}$ tank to simulate a $400 \mathrm{~L}$ tank but not by calculation. For example, the temperature of the 1st generation tank in the first row was $58.5^{\circ} \mathrm{C}$ after 1 person taking a bath (this temperature was the actual measurement). If by calculation, the temperature would be: $\left(350 \times 60{ }^{\circ} \mathrm{C}+50 \times 20^{\circ} \mathrm{C}\right) / 400=55^{\circ} \mathrm{C}$.

Table 1. The bath water consumption during simulation.

\begin{tabular}{cccc}
\hline $\begin{array}{c}\text { The Size of the } \\
\text { Original Tank }\end{array}$ & $\begin{array}{c}\text { Average Bath } \\
\text { Amount per Person }\end{array}$ & Proportion & $\begin{array}{c}\text { Relative Bath Water Volume } \\
\text { of } \mathbf{2 0 0 0} \text { mL Experiment Tank }\end{array}$ \\
\hline $100 \mathrm{~L}$ & $50 \mathrm{~L}$ & $50.00 \%$ & $1000.0 \mathrm{~mL}$ \\
\hline $200 \mathrm{~L}$ & $50 \mathrm{~L}$ & $25.00 \%$ & $500.0 \mathrm{~mL}$ \\
\hline $300 \mathrm{~L}$ & $50 \mathrm{~L}$ & $16.67 \%$ & $333.3 \mathrm{~mL}$ \\
\hline $400 \mathrm{~L}$ & $50 \mathrm{~L}$ & $12.50 \%$ & $250.0 \mathrm{~mL}$ \\
\hline $600 \mathrm{~L}$ & $50 \mathrm{~L}$ & $8.33 \%$ & $166.7 \mathrm{~mL}$ \\
\hline $800 \mathrm{~L}$ & $50 \mathrm{~L}$ & $6.25 \%$ & $125.0 \mathrm{~mL}$ \\
\hline
\end{tabular}


Table 2. List of instruments adopted for this experiment.

\begin{tabular}{cccc}
\hline Device Name & Accuracy & Type \\
\hline Thermometer & $\pm 0.1^{\circ} \mathrm{C}$ or $\pm 0.1^{\circ} \mathrm{F}$ & BOSCH GIS 500 \\
Feeding Syringe & $\pm 2 \mathrm{CC}$ & None \\
\hline Heating Equipment & & & \\
\hline
\end{tabular}

Table 3. Results of hot water experiments on simulation of various tanks from the 1st to the 3rd generations.

\begin{tabular}{|c|c|c|c|c|c|c|}
\hline $\begin{array}{l}\text { Number of Baths } \\
\text { Storage Tank }\end{array}$ & $\begin{array}{l}\text { After 1st } \\
\text { Shower }\end{array}$ & $\begin{array}{l}\text { After 2nd } \\
\text { Shower }\end{array}$ & $\begin{array}{l}\text { After 3rd } \\
\text { Shower }\end{array}$ & $\begin{array}{l}\text { After 4th } \\
\text { Shower }\end{array}$ & $\begin{array}{l}\text { After 5th } \\
\text { Shower }\end{array}$ & $\begin{array}{l}\text { After 6th } \\
\text { Shower }\end{array}$ \\
\hline $\begin{array}{l}\text { No dividing disk } \\
\text { (1st generation) }\end{array}$ & $58.5^{\circ} \mathrm{C}$ & $55.3^{\circ} \mathrm{C}$ & $52.0^{\circ} \mathrm{C}$ & $47.5^{\circ} \mathrm{C}$ & $42.3^{\circ} \mathrm{C}$ & $37.2^{\circ} \mathrm{C}$ \\
\hline $\begin{array}{l}1 / 20 \text { position } \\
\text { (2nd generation) }\end{array}$ & $58.5^{\circ} \mathrm{C}$ & $55.0^{\circ} \mathrm{C}$ & $53.0^{\circ} \mathrm{C}$ & $50.0^{\circ} \mathrm{C}$ & $45.5^{\circ} \mathrm{C}$ & $41.0^{\circ} \mathrm{C}$ \\
\hline $\begin{array}{l}\text { 2/20 position } \\
\text { (2nd generation) }\end{array}$ & $59.0^{\circ} \mathrm{C}$ & $57.0^{\circ} \mathrm{C}$ & $54.5^{\circ} \mathrm{C}$ & $51.2^{\circ} \mathrm{C}$ & $46.3^{\circ} \mathrm{C}$ & $41.5^{\circ} \mathrm{C}$ \\
\hline $\begin{array}{l}3 / 20 \text { position } \\
\text { (2nd generation) }\end{array}$ & $58.1^{\circ} \mathrm{C}$ & $56.0^{\circ} \mathrm{C}$ & $52.3^{\circ} \mathrm{C}$ & $48.5^{\circ} \mathrm{C}$ & $44.0^{\circ} \mathrm{C}$ & $39.5^{\circ} \mathrm{C}$ \\
\hline $\begin{array}{l}4 / 20 \text { position } \\
\text { (2nd generation) }\end{array}$ & $58.5^{\circ} \mathrm{C}$ & $56.2^{\circ} \mathrm{C}$ & $53.0^{\circ} \mathrm{C}$ & $48.5^{\circ} \mathrm{C}$ & $43.6^{\circ} \mathrm{C}$ & $38.8^{\circ} \mathrm{C}$ \\
\hline $\begin{array}{l}5 / 20 \text { position } \\
\text { (2nd generation) }\end{array}$ & $58.7^{\circ} \mathrm{C}$ & $55.0^{\circ} \mathrm{C}$ & $51.0^{\circ} \mathrm{C}$ & $46.2^{\circ} \mathrm{C}$ & $42.0^{\circ} \mathrm{C}$ & $37.0^{\circ} \mathrm{C}$ \\
\hline $\begin{array}{l}\text { 6/20 position } \\
\text { (2nd generation) }\end{array}$ & $59.2^{\circ} \mathrm{C}$ & $56.2^{\circ} \mathrm{C}$ & $51.5^{\circ} \mathrm{C}$ & $46.8^{\circ} \mathrm{C}$ & $42.0^{\circ} \mathrm{C}$ & $37.7^{\circ} \mathrm{C}$ \\
\hline $\begin{array}{l}\text { 7/20 position } \\
\text { (2nd generation) }\end{array}$ & $59.2^{\circ} \mathrm{C}$ & $56.3^{\circ} \mathrm{C}$ & $51.8^{\circ} \mathrm{C}$ & $47.2^{\circ} \mathrm{C}$ & $42.3^{\circ} \mathrm{C}$ & $38.0^{\circ} \mathrm{C}$ \\
\hline $\begin{array}{l}8 / 20 \text { position } \\
\text { (2nd generation) }\end{array}$ & $59.1^{\circ} \mathrm{C}$ & $56.5^{\circ} \mathrm{C}$ & $52.0^{\circ} \mathrm{C}$ & $48.0^{\circ} \mathrm{C}$ & $42.5^{\circ} \mathrm{C}$ & $38.2^{\circ} \mathrm{C}$ \\
\hline $\begin{array}{l}\text { 9/20 position } \\
\text { (2nd generation) }\end{array}$ & $59.1^{\circ} \mathrm{C}$ & $55.9^{\circ} \mathrm{C}$ & $51.9^{\circ} \mathrm{C}$ & $47.9^{\circ} \mathrm{C}$ & $42.3^{\circ} \mathrm{C}$ & $38.5^{\circ} \mathrm{C}$ \\
\hline $\begin{array}{l}\text { 10/20 position } \\
\text { (2nd generation) }\end{array}$ & $59.0^{\circ} \mathrm{C}$ & $55.0^{\circ} \mathrm{C}$ & $52.0^{\circ} \mathrm{C}$ & $48.0^{\circ} \mathrm{C}$ & $42.2^{\circ} \mathrm{C}$ & $39.0^{\circ} \mathrm{C}$ \\
\hline $\begin{array}{l}\text { Movable dividing disk } \\
\quad \text { (3rd generation) }\end{array}$ & $59.5^{\circ} \mathrm{C}$ & $58.9^{\circ} \mathrm{C}$ & $58.5^{\circ} \mathrm{C}$ & $58.0^{\circ} \mathrm{C}$ & $57.6^{\circ} \mathrm{C}$ & $57.2^{\circ} \mathrm{C}$ \\
\hline
\end{tabular}

Why was the temperature obtained from the calculation $55^{\circ} \mathrm{C}$ but the actual temperature measured by thermometer was $58.5^{\circ} \mathrm{C}$ ? That is because after one person took a bath, cold water would fill in from the right side of the tank, and the hot water outlet is at the far left side (it is where the temperature was measured during the experiment because the temperature there was the closest to the temperature 
of our bath), so the hot and cold water is not completely and fully mixed. In other words, the water temperature inside the tank was unevenly distributed, and the condition presented was that the temperature near the hot water outlet on the left was higher, while that near the cold water injection outlet on the right was lower. Of course, if the hot and cold water were mixed for several hours, the measured temperature would be closer to the calculated value (but then the actual temperature might be lower than $55^{\circ} \mathrm{C}$ because of the limited heat retention capacity of the water storage tank).

In Table 3, the temperature of the water storage tank of the no dividing disk (1st generation) after the 6th shower was $37.2^{\circ} \mathrm{C}$. If the heating rod started to be heated to $60^{\circ} \mathrm{C}$ at this time, it will consume energy at this time: $37,000 \times(400 / 1000) \times((60-37.2) /(60-23))=9120 \mathrm{Kcal}$ (it is mentioned in [9] that $1000 \mathrm{~L}$ of cold water needs $37,000 \mathrm{Kcal}$ to be heated from 23 degrees to 60 degrees). The temperature of the water storage tank of the movable dividing disk (3rd generation) after the 6th shower was $57.2^{\circ} \mathrm{C}$. If the heating rod is turned on at this time to be heated to $60^{\circ} \mathrm{C}$, it will only consume energy at this time: $37,000 \times(400 / 1000) \times((60-57.2) /(60-23))=1120 \mathrm{Kcal}$. The energy consumption of the 3rd generation water storage tank was only $12.28 \%$ of that of the first-generation water storage tank $(9120 / 1120=0.1228)$.

The above experiment is the average results of the two experiments. From the data, it is found that the 3rd generation water heating tank developed by us had the best temperature performance. After 6 persons taking baths, the temperature of hot water was still at $57.2^{\circ} \mathrm{C}$, with its theoretical value being $60.0^{\circ} \mathrm{C}$, the temperature still dropped from 60.0 to $57.2^{\circ} \mathrm{C}$, mainly because of the loss of temperature inside the water storage tank. This is the error caused by poor insulation of the water storage tank.

In addition, from the experimental data of Table 3, it is known that the 2nd generation water heating tank had the best temperature performance when the "fixed dividing disk" was placed at the $2 / 20$ position. The temperature performance was $41.0^{\circ} \mathrm{C}$ when the dividing disk was at the $1 / 20$ position, already much better than $37.2{ }^{\circ} \mathrm{C}$ without the disk. The temperature performance was best when the dividing disk was at the $2 / 20$ position, and then slowly dropped to $37.0^{\circ} \mathrm{C}$ at the $5 / 20$ position, which was similar to the $37.2{ }^{\circ} \mathrm{C}$ without the disk. It means that if the fixed dividing disk was installed at the $5 / 20$ position; it is about the same as having no dividing disk at all. When its position was moved back, the temperature would slowly rise again. Since the two sides of the storage tank were symmetrical, the temperature at the $18 / 20$ position was expected to be similar to that at the $2 / 20$ position.

Since the 2nd generation water heating tank had the best temperature performance when the "fixed dividing disk" was placed at the $2 / 20$ position, the original temperature of the hot water was $60^{\circ} \mathrm{C}$, and the temperature of hot water was $41.5^{\circ} \mathrm{C}$ after 6 persons took baths, which means the temperature performance was best when the buffer area accounted for about $10 \%$ of the entire water heating tank. As the 4 th generation solar water heating tank can be seen as a combination of the 2 nd generation and 3rd generation solar water heating tank, the "heating area" of the 4th generation water heating tank was also proposed to take up about $10 \%$ of the whole water heating tank, as shown in Figure 11.

When the first tank of hot water is used up and a secondary heating with an electric heating rod is required, as the "heating area" takes up only $10 \%$ of the entire water heating tank, there is no need to reheat the entire tank of water, and about $90 \%$ of the energy can be saved in that instance. 


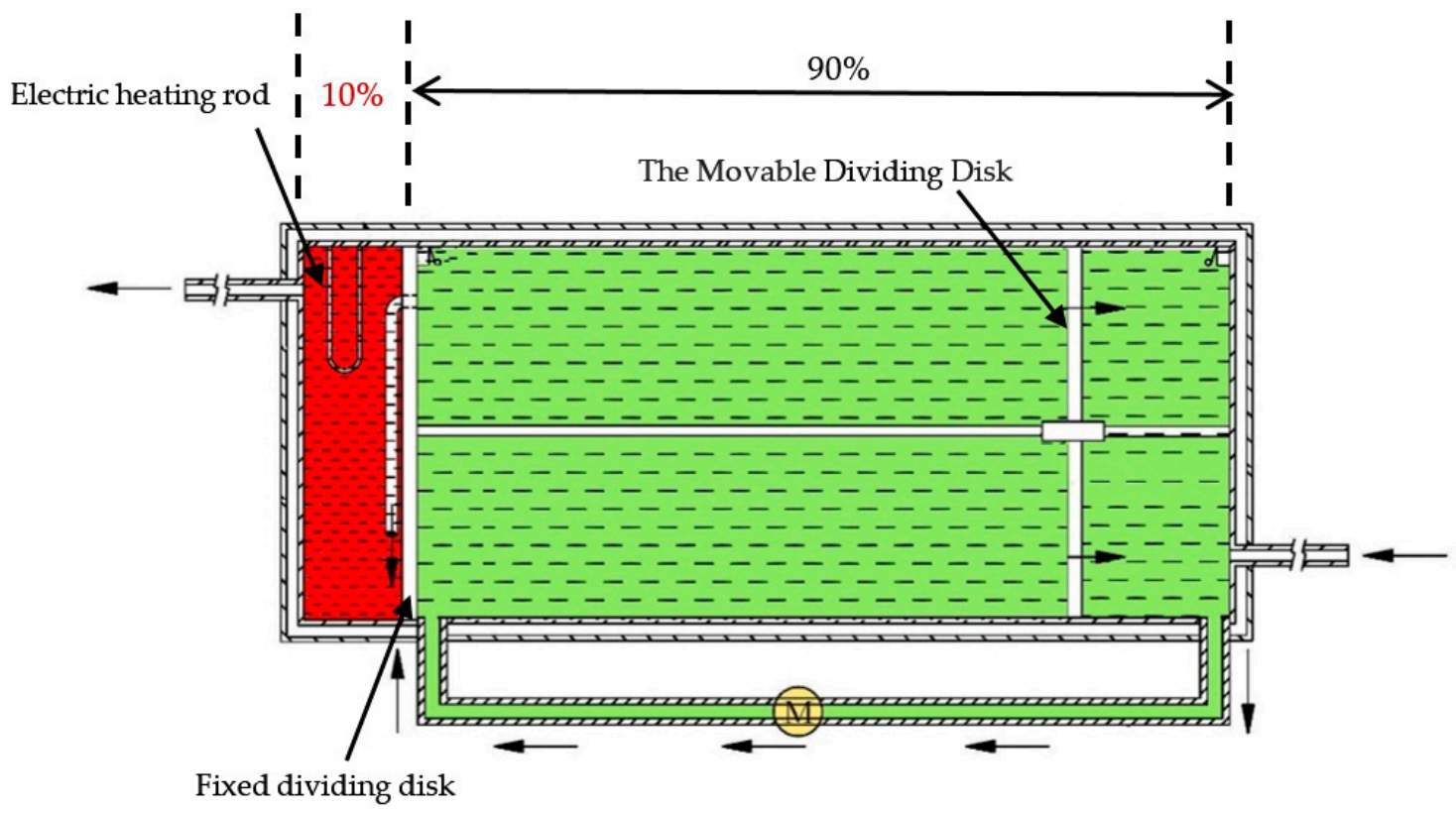

Figure 11. Proportional location of the fixed dividing disk of the 4 th generation water heating tank.

Since the 4th generation solar water heating tank is an evolutionary version of the 3rd generation solar water heating tank, the advantages and disadvantages are summarized as Table 4:

Table 4. Comparison of 3rd and 4th generation solar water heating tanks.

\begin{tabular}{ccc}
\hline Solar Water Heating Tank & 3rd Generation & 4th Generation \\
\hline Advantage & $\begin{array}{c}\text { It can completely separate hot and } \\
\text { cold water so that hot and cold } \\
\text { water do not mix up. }\end{array}$ & $\begin{array}{c}\text { It can completely separate the hot and } \\
\text { cold water. When the first tank of hot } \\
\text { water is used up, only partial reheating is } \\
\text { required, rather than having to reheat the } \\
\text { entire tank. }\end{array}$ \\
Disadvantage & $\begin{array}{c}\text { When the first tank of hot water is } \\
\text { used up, the entire tank must be } \\
\text { reheated or an additional small } \\
\text { water heating tank is required. }\end{array}$ & $\begin{array}{c}\text { There is an extra dividing disk for the } \\
\text { establishment of cold-water heating area. }\end{array}$ \\
\hline
\end{tabular}

Finally, the 4th generation water heating tank can be regarded as a combination of the 2nd generation and 3rd generation water heating tank. It has the advantages of $100 \%$ hot water use in the 3rd generation water heating tank. When the water is depleted, the 2nd generation water heating tank can also play the role of blocking, only for local heating of small areas, so this hot water tank can be regarded as the best solution at present. Moreover, the cost of a general hot water tank is about US $\$ 125$. The 4th generation water heating tank adds the movable dividing disk, fixed dividing disk and pumping motor, so the total cost will increase about US\$31.25, which is about $25 \%$ of the total cost.

\section{Conclusions}

In the era of environmental awareness, the application of renewable energy and the development of green energy technology are gradually being emphasized. Many products around the world have been developed with the aspirations of energy saving, environmental protection and cherishing the Earth's resources. This study successfully developed the 3rd generation solar water heating tank, and designing a "mobile dividing disk" to avoid the issue of mixing of hot and cold water that occurred in the 1st and 2nd generation solar water heating tanks. As a result, the hot and cold water could be completed separated, moreover the whole tank of hot water could be $100 \%$ utilized. 
However, there is still an invisible drawback to that new design. When the hot water runs out and a secondary heating is required, the whole tank must be heated with an electric heating rod, or an additional small storage tank must be added for reheating. To address this problem, the 4th generation solar water heating tank was developed in this article. An additional "fixed dividing disk" is designed to be added inside the tank, and the separated heating area uses an electric heating rod for secondary heating, which saves $90 \%$ of energy and electricity cost in that instance compared to heating the entire tank of water, while eliminating the cost of making a small additional heating tank, thus saving energy and reducing carbon emissions. This improvement was the most important feature of this work, making this work more suitable for living needs and more convenient.

The 4th generation water heating tank proposed in this article can not only be used in solar water heaters, in fact, it can be used as long as it needs to store hot water in a water tank, such as gas water heaters, power heaters, heat pump water heaters, etc., are all applicable. Therefore, if this 4th generation water heating tank can be commercialized, thus it will greatly contribute to energy saving and carbon reduction. Furthermore, the cost of a general hot water tank is about US\$125. The 4th generation water heating tank adds a movable dividing disk, fixed dividing disk and pumping motor, so the total cost will increase to about US $\$ 31.25$, which is about $25 \%$ of the total cost.

Author Contributions: Conceptualization, C.-T.L. and P.-T.H.; methodology, C.-T.L.; software, P.-T.H.; validation, P.-T.H., Y.-Y.L., and L.-B.C.; formal analysis, C.-T.L. and P.-T.H.; investigation, Y.-Y.L.; resources, Y.-Y.L.; data curation, P.-T.H.; writing - original draft preparation, C.-T.L. and P.-T.H.; writing-review and editing, C.-T.L., P.-T.H. and L.-B.C.; visualization, C.-T.L.; project administration, P.-T.H. and L.-B.C. All authors have read and agreed to the published version of the manuscript.

Funding: This research received no external funding.

Conflicts of Interest: The authors declare no conflict of interest.

\section{References}

1. Tso, G.K.F.; Yau, K.K.W. A study of domestic energy usage patterns in Hong Kong. Int. J. Energy 2003, 28, 1671-1682. [CrossRef]

2. Lutz, J.D.; Whitehead, C.D.; Lekov, A.B.; Rosenqist, G.J.; Winiarsk, D.W. WHAM: Simplified tool for calculating water heater energy use. ASHRAE Trans. 1999, 105, 1005-1015.

3. Hegazy, A.A. Effect of inlet design on the performance of storage-type domestic electrical water heaters. Appl. Energy 2007, 84, 1338-1355. [CrossRef]

4. Chiou, S.-R. Effect of Light Emitting Diode Lumileds and Photovoltaic on Electric system in Taiwan. Master's Thesis, National Cheng Kung University, Tainan, Taiwan, 2007.

5. HM Government. Meeting the Energy Challenge-A White Paper on Energy. Available online: https://assets. publishing.service.gov.uk/government/uploads/system/uploads/attachment_data/file/243268/7124.pdf (accessed on 21 May 2019).

6. China Eyes $20 \%$ Renewable Energy by 2020. Available online: https://www.chinadaily.com.cn/china/2009-06/ 10/content_8268871.htm (accessed on 10 March 2019).

7. Lee, C.K.; Li, S.; Hui, S.Y. A Design Methodology for Smart LED Lighting Systems Powered By Weakly Regulated Renewable Power Grids. IEEE Trans. Smart Grid 2011, 2, 548-554. [CrossRef]

8. Taiwan Service Center Energy-Saving Plan. Available online: http://blog.udn.com/escos/8612177 (accessed on 10 March 2019).

9. National Cheng Kung University Research Development Foundation. Solar Water Heating Systems Industry Skilled Workshop; National Cheng Kung University: Tainan, Taiwan, 2013.

10. ITRI Energy Resources. Solar Hot Water System Of Professional And Technical Personnel Workshops; Industrial Technology Research Institute: Taipei, Taiwan, 2001.

11. Chen, T.J.; Shr, J.W.; Ying, J.M. Summary of Israeli law and solar reflection. Sol. New Energy J. 2003, 8, 13-15.

12. Comparative Analysis of Solar Water Heaters and Heat Pump Water Heater Energy Efficiency. Available online: http://tw.myblog.yahoo.com/mrsaving/arti (accessed on 8 August 2019).

13. Kepplinger, P.; Huber, G.; Preißinger, M.; Petrasch, J. State estimation of resistive hot water heaters in arbitrary operation modes for demand side management. Therm. Sci. Eng. Prog. 2019, 9, 94-109. [CrossRef] 
14. Kizilors, C.; Aydin, D. Effect of thermostat position and its set-point temperature on the performance of a domestic electric water heater. Int. J. Low-Carbon Technol. 2020, 15, 373-381. [CrossRef]

15. Aviv, A.; Blyakhman, Y.; Beeri, O.; Ziskind, G.; Letan, R. Experimental and numerical study of mixing in a hot-water storage tank. J. Sol. Energy Eng. 2009, 131, 11011. [CrossRef]

16. Assari, M.R.; Tabrizi, H.B.; Savadkohy, M. Numerical and experimental study of inlet-outlet locations effect in horizontal storage tank of solar water heater. Sustain. Energy Technol. Assess. 2018, 25, 181-190.

17. National Cheng Kung University Energy Research Center-Solar Water Heater Types. Available online: http://solar.rsh.ncku.edu.tw/t01_kind.php (accessed on 28 November 2019).

18. Bin, C.R. The Improvement on Solar Water Heating Tank. Patent Publication M396945, 21 January 2011.

19. Lee, C.-T.; Chu, H.-M. The Research on Best position of dividing disk of the 2nd Generation Energy Saving Solar Water Heating Tank. Eur. J. Mater. Sci. Eng. 2018, 3, 42-48.

20. Lee, C.-T. A Research on the New Type Solar Water Heating Tank with Energy Saving. Eur. J. Mater. Sci. Eng. 2019, 4, 67-74. [CrossRef]

21. Lee, C.-T.; Chu, H.-M. A Research on the Energy Saving 3rd Generation Solar Water Heating Tank. J. Cheng Shiu Univ. 2018, 31, 17-26.

Publisher's Note: MDPI stays neutral with regard to jurisdictional claims in published maps and institutional affiliations.

(C) 2020 by the authors. Licensee MDPI, Basel, Switzerland. This article is an open access article distributed under the terms and conditions of the Creative Commons Attribution (CC BY) license (http://creativecommons.org/licenses/by/4.0/). 